\title{
New records of fertile Rhyniophytina from the late Silurian of Wales
}

\author{
D. EDWARDS \& E. C. W. ROGERSON
}

(Plate 1)

Summary. Whitcliffian and Downtonian macroplants of rhyniophyte morphology are described from Capel Horeb Quarry, Powys, Wales. Both floras contain Hostinella Stur, Cooksonia Lang and Steganotheca Edwards. They are briefly compared with others of similar age, and the contribution, particularly of the Whitcliffian assemblage, to our knowledge on the early colonisation of the land by vascular plants is discussed.

\section{Introduction}

It is a fitting tribute to the insight and enthusiasm of Professor H. P. Banks, Cornell University, who retired in 1978, that the recent upsurge of interest in the early evolution of land plants should have been stimulated to a very great extent by his critical reviews of the subject. These stress the value of detailed and accurate documentation. Our own research in this field centres on the South Wales area where we are describing micro- and macroplant fossils throughout the Ludlow and Downton Series. One of our most productive sites is the Capel Horeb Quarry on the A40 road $5 \mathrm{~km} \mathrm{~W}$ of Trecastle, Powys. In 1976, we recorded in the Whitcliffian strata the oldest in situ tracheids, together with Cooksonia sporangia (Edwards \& Davies, 1976) while Edwards (1970) described Steganotheca striata Edwards, a presumed rhyniophyte from the younger Downtonian sediments. In this paper we report Steganotheca sporangia in the Whitcliffian rocks and Cooksonia from the Downton Series. Thus, as recorded in this quarry, the composition of late Ludlovian and early Downtonian floras is identical, the only difference being that the younger plants are less fragmentary.

The importance of the Whitcliffian assemblage cannot be overestimated. The only record of probable vascular plant macrofossils in the late Ludlovian stage comes from Podolia, where Ishchenko (1975) described a compression fiora from the Rashkov Beds in the Skala horizon. The Welsh Downtonian records are perhaps less exciting, merely confirming the widespread occurrence of the best known early vascular plant genus, Cooksonia in the late Silurian of southern Britain.

\section{Stratigraphy and preservation}

Capel Horeb or Halfway Quarry (Nat. Grid. Ref. SN83 8443 3234) is mentioned in the Cwm Dwr Section in Potter \& Price's description (1965) of the Ludlovian-Downtonian rocks of the south limb of the Towy anticline. Fragmentary plants preserved as coalified compressions occur in both the Upper Roman Camp and the Long Quarry Beds. The former contain a fauna of essentially Whitcliffian aspect (considered by those authors to be Lower Whitcliffe) and are overlain unconformably by the Long Quarry Beds, which are interpreted, again on faunal evidence, to be equivalent to the lowermost Downtonian series of the Welsh Borderland. Although poorly preserved, the dispersed spore assemblage supports these conclusions (Richardson \& Lister, 1969).

Very small plant fragments are occasionally found throughout the Upper Roman Camp Beds, but they occur in greatest numbers in grey blue siltstone layers near the top. Our collections were made from the bedding planes, exposed on the nearly vertical face in the $\mathrm{N}$ corner of the quarry and from the extensive spoil heaps below the face. In addition to the smooth, narrow, parallel-sided, 
sometimes dichotomously branched axes, are less regular wider ones assignable to Prototaxites. Also present are small patches of coalified material which cannot be identified with the naked eye and which are the subject of a separate investigation.

The specimens on which the diagnosis of Steganotheca striata was made came from a layer of grey flaggy siltstone some $10 \mathrm{~m}$ above the base of the Downtonian Stage. More recent collections come from the spoil heap below this layer. Potter \& Price (1965) had earlier noted plant debris near the base of the Long Quarry Beds and it was presumably from these horizons that Heard (1939) originally described Cooksonia downtonensis which Edwards (1970) transferred to the new taxon $S$. striata. Very little structure remains in these coalified compressions (sensu Schopf, 1975). Bulk maceration of the matrix sometimes yields small fragments of cuticle, but most of this is of Nematothallus type. Film pulls were more informative, fragments of cell walls or tracheids being occasionally recovered from axes and spores from sporangia.

\section{Descriptions and discussion}

\section{3.a. Plants from the Upper Roman Camp Beds (Whitcliffian)}

3.a.I. Steganotheca striata

Although this species was originally described from the Downtonian Long Quarry Beds in the quarry, it has not been previously recorded from older rocks. The recently collected Whitcliffian representatives are much more fragmentary, each specimen usually consisting of an elongate sporangium terminating a short length of parallel-sided, unbranched axis. The diagnostic features of $S$. striata sporangia, the obliquely running striations and the terminal thicker lens-shaped region are usually clearly visible. A well preserved sporangium with strongly ridged surface is illustrated in Plate $1 o$ and $p$. Here the much flatter terminal region is almost circular in outline. In the majority of cases however, although the distal region persists, the organic material of the main body of the sporangium has flaked off leaving dark strands adhering to the rock surface (PI. $1 j, k, m$ and $n$ ).

The nature and function of the more heavily thickened terminal region remain obscure; whether the thickening is merely the result of compression of the truncated apex of the sporangium or whether it is a structural feature, e.g. comparable to the operculum of a bryophyte and hence concerned with dehiscence, cannot be determined.

The Whitcliffian specimens show greater variation in shape and size than the younger representatives. The squat sporangia illustrated in Plate $1 k$ and $l$ are most typical of the majority of the Downtonian forms. Many of the new specimens are more slender (PI. $1 j$ ); the junction between sporangium and subtending axis being difficult to delimit (PI. $1 j$ ). Long narrow sporangia are seen in the only branching specimen found (Pl. 1e). These are small but readily identified as Steganotheca by the distinctive apical thickenings. A few Whitcliffian examples of less certain affinity have rounded apices (PI. If).

The Whitcliffian specimens also show a greater size range. Considering height, the new specimens range between 1.7 and $4.4 \mathrm{~mm}$ compared with 1.8 and $2.7 \mathrm{~mm}$ in the Downtonian forms. Similarly sporangial width is between 0.45 and $1.7 \mathrm{~mm}$ in the Whitcliffian and 1.0 and $1.5 \mathrm{~mm}$ in the Downtonian. The largest Whitcliffian sporangia (e.g. $4.4 \mathrm{~mm}$ long by $1.05 \mathrm{~mm}$ wide, 3.7 $\mathrm{mm}$ long by $1.7 \mathrm{~mm}$ wide) tend to be narrower. Finally although there are a few specimens of similar size (Pl. 1k) Whitcliffian strata contain the smallest sporangia (e.g. $1.08 \mathrm{~mm}$ long by 0.8 mm wide).

The uniformity in size and shape of the Downtonian sporangia may be due to their having come from just three specimens. The twenty isolated sporangia collected from the Upper Roman Camp Beds probably came from as many plants. 


\section{3.a.2. Cooksonia sporangia}

We have already briefly mentioned the presence of this, the most completely known late Silurian vascular plant, in the Upper Roman Camp Beds (Edwards \& Davies, 1976). Again the specimens are fragmentary, only one showing characteristic branching (Pl. 1 g). Of the 18 intact sporangia collected, a third are directly attributable to Lang's $C$. hemisphaerica. A typical example is illustrated in Plate $1 a$. The almost isodiametric spore containing region ( $1.3 \mathrm{~mm}$ wide) is clearly delimited. Some sporangia yield spores which are psilate and occasionally bear tri-radiate marks. The majority of the remaining specimens are too incompletely preserved to permit specific identification, but their short and wide sporangia are characteristic of the genus Cooksonia. Finally we have found a single example of a short and wide sporangium of Cooksonia type which is distinguished by a narrow border, $0.15 \mathrm{~mm}$ wide extending around the free part of the sporangium and narrowing slightly to $0.01 \mathrm{~mm}$ at the contact with the axis ( $\mathrm{Pl}$. 1d). Most of the coalified material of the sporangium itself has disappeared and unfortunately a circular area of a rusty substance completely obliterates the junction between sporangium and axis. The sporangium is subtended by a short, smooth, unbranched axis $0.3 \mathrm{~mm}$ wide below and increasing to $0.9 \mathrm{~mm}$ at the sporangium junction.

This specimen most closely resembles $C$. caledonica from the Dittonian of Scotland, but because of its fragmentary nature and the lack of evidence for a curved junction between sporangium and axis it will be left as cf. $C$. caledonica.

\section{3.a.3. Sporangia of uncertain affinity}

There is a very small number of specimens where sporangial height is greater than width, which hence do not conform to Lang's generic concept of Cooksonia. That illustrated in Plate $1 b$ is elliptical in outline, being $0.95 \mathrm{~mm}$ high and $0.85 \mathrm{~mm}$ wide. Plate $1 c$ shows the longest, although rather poorly preserved specimen $1.25 \mathrm{~mm}$ high and $0.8 \mathrm{~mm}$ wide and is elliptical to ovate in outline.

There are examples of elongate sporangia terminating naked axes in late Silurian and early Devonian rocks with similar proportions, shape and size to the Capel Horeb forms. They include Eogaspesiea Daber, Eorhynia Ishchenko and certain specimens of Sporogonites Halle and Taeniocrada White. None are identical with the Welsh fossils: indeed we feel that detailed comparisons involving such fragmentary material are premature and that our elongate sporangia should remain unnamed.

\section{3.b. Plants from the Long Quarry Beds (Downtonian)}

\section{3.b.l. Cooksonia sp.}

Specimen NMW 77 34G 12 (PI. $1 \mathrm{~h}$ ) is the only one we have found showing typical Cooksonia morphology. It is $17.0 \mathrm{~mm}$ high with the smooth axes varying between 0.3 and $0.35 \mathrm{~mm}$ in width but widening considerably below the single branching point. The most complete sporangium which terminates the right hand branch is oval in outline, $0.9 \mathrm{~mm}$ high and $1.2 \mathrm{~mm}$ wide. It has a granular appearance and bevelled edges. The left-hand one is incompletely preserved but shows clearly the junction between sporangium and axis, there being little change in axis diameter immediately below the sporangium.

Comparing this specimen with Lang's two species from the Downtonian, it shows greatest similarities with $C$. pertonii from the Welsh Borderland. The type species, however, has more strongly flattened, tangentially extended sporangia with an extensive axis attachment. The new specimen has more in common with the sporangium illustrated by Obrhel (1962) in his plate 1, figs 4 and 5 and like him we choose to call our specimen Cooksonia sp. 


\section{3.b.2. Specimen NMW $7734 G 13$}

The fragment illustrated in Plate $1 i$ was found on the reverse side of a rock with typical Steganotheci axes. The face itself shows slicken siding and very little carbon remains on the fossil. Its overall height is $5.5 \mathrm{~mm}$ with the 'main' axis $0.2 \mathrm{~mm}$ wide at its base tapering to 0.15 $\mathrm{mm}$ distally. The axes are smooth, but unlike Cooksonia lack regular dichotomous branching except at the ultimate branch point; instead a cluster of three apparently lateral branches is given off the left hand side of the axis. These branch once and then terminate in swollen bodies interpreted as sporangia. The most complete of these is globular (approximately $0.6 \mathrm{~mm}$ high and $0.6 \mathrm{~mm}$ wide) and tapers into the axis beneath. A detached similar but smaller structure resembling a small Cooksonia is present in the matrix alongside the main axis. The products of the ultimate dichotomy of the 'main' axis also terminate in sporangia. Neither anatomical detail nor spores have been obtained from the fossil.

Considering just sporangium morphology, the specimen shows some similarities with Lang's $C$. hemisphaerica, but its overall organisation is more complex. Indeed we have found nothing similar in any of our investigations on Downtonian floras of Britain (see for example Edwards, in the press.) Obrhel described a highly branched form with Cooksonia type sporangia from late Silurian of Czechoslovakia (P. ultimus zone) (Obrhel, 1962, Pl. 1, figs 1 and 2), but the branching pattern and sporangium morphology are quite different.

Ananiev \& Stepanov (1969) emended the specific diagnosis of $C$. hemisphaerica Lang, based on new material from Siberia. Many authors (Banks, $1975 c$; Gensel, 1976; Edwards, 1979) have questioned their decision. It is possible, but we consider it highly unlikely, that our Whitcliffian specimen is a small fragment, possibly a 'lateral branch' of a much larger specimen similar to the Siberian fossils. The sporangial morphology is quite different, the Welsh specimens lacking borders and being more or less isodiametric rather than elongate.

In conclusion, we decided to leave this specimen unnamed until better material is found.

\section{General discussion}

The flora in the Upper Roman Camp Beds is possibly the oldest containing macroplants with gross morphology typical of the Rhyniophytina, although direct anatomical evidence for vascular tissue is somewhat disappointing. Whereas we have been able to show that some of the sterile axes are vascular, we have failed to demonstrate tracheids in Steganotheca and Cooksonia. The latter is, however, known to be vascular from Lang's work on Downtonian floras (Lang, 1937). Thus we are confident that terrestrial vegetation composed of vascular plants existed in late Ludlovian times. The habitats of the plants are unknown. They are preserved in a very fragmentary condition in near-shore marine deposits, but whether they colonized mudflats or salt marshes bordering the sea or were transported by rivers from further inland cannot be determined.

The subsequent history of vascular plants in late Silurian and early Devonian times is well documented elsewhere (Banks, 1972, 1975a). The composition of Downtonian floras is remarkably uniform being dominated by the higher green plants Hostinella and Cooksonia but also containing the more enigmatic, possibly algal, genera Prototaxites Dawson, Pachytheca Hooker and Nematothallus Lang. Such plants of widely separate affinity are all considered to be early colonisers of the land (Banks, 1977; Lang, 1937). It is possible that the paucity of taxa results from a lack of records in continental deposits, the majority of floras having been described from marine sediments. Lang (1937) however recorded similar plant remains in marine, brackish and fluviatile sediments in the Downtonian of the Welsh Borderland and South Wales. In addition the two floras which exhibit greatest diversity have been described from marine sediments (Edwards, in the press; Ishchenko, 1975). The Russian flora is of interest in that it 
is closest in age, though slightly younger than the Capel Horeb Whitcliffian one. It was collected from the Rashkov Beds (Skala horizon) in Podolia and these extend from the top of the Ludlow into the Downton Series (Nikiforova, 1977). The plants are preserved as compressions and lack any anatomical detail. In addition to Cooksonia, the flora contains a new genus Eorhynia in which elongate sporangia terminate smooth axes with occasional dichotomous branching. Further up the beds Ishchenko records Zosterophyllum but the specimen illustrated is very fragmentary and it is difficult to distinguish sporangia. Also described is a further new genus Lycopodolica in which ?branching axes are covered with hair-like enations. The remaining plants are even more fragmentary.

Considering now the even earlier history of vascular plants, we have found dichotomously branching axes similar in morphology to Hostinella throughout the marine Ludlow Series in South Wales. In older rocks they occur in graptolitic shales, while in younger sediments they are associated with shelly faunas. Although some of these axes have a distinct central line occupying the usual position of conducting tissue, we have not yet isolated tracheids. Axes with similar external morphology but which are not considered vascular were recorded from the Llandovery Series of the United States (Schopf et al., 1966). The name Eohostimella was given to cylindrical axes, some showing dichotomous branching, characterised by a persistent cortex and minutely spinose surfaces. Had such axes been found in later rocks they would undoubtedly have been assigned to Hostinella, but the authors, wishing to emphasise the lack of vascular tissue, placed them in a new genus. They did, however, consider the axes to belong to erect land plants; support for the aerial system being provided by thick walled cells in the outer cortex rather than from vascular tissue.

Much of the recent discussion on the early colonization of the land by plants has been based on dispersed microfossils (Banks, $1975 b$; Gray \& Boucot, 1977). We consider it highly unlikely that tracheids with annular thickenings such as have been described from late Silurian and early Devonian plants would remain intact on the disintegration of the remaining tissues of the plant, and hence would not be found as isolated elements. We also believe that while fragments of cuticle and wide tubes with tracheidal-like thickenings (such as are found in the Nematothallus complex) indicate that plants had evolved with anatomical adaptations for existence in terrestrial environments, in the absence of gross morphology, three-dimensional anatomy and reproductive parts, the affinities of such plants must remain obscure. We therefore conclude that the most acceptable evidence for vascular plants in the early Silurian will be from axes with in situ tracheids. As Banks (1972) pointed out, this will mean a thorough analysis of even the most fragmentary plant debris, hitherto considered too unpromising for investigation, but which may well replace speculation on the origin and early evolution of vascular plants with facts.

Acknowledgements. E. C. W. Rogerson is employed on an N.E.R.C. Research Grant. We thank Dr M. G. Bassett (National Museum of Wales) for helpful discussion.

\section{References}

Ananiev, A. R. \& Stepanov, S. A. 1969. The first finding of the Psilophyton flora in Lower Devonian Salairsky Ridge (Western Siberia). Publ. Tomsk State Univ. 203, 13-28. (In Russian.)

Banks, H. P. 1972. The stratigraphic occurrence of early land plants. Palaeontology 15, 365-77.

Banks, H. P. 1975 (a). Palaeogeographic implications of some Silurian-Early Devonian floras. In Gondwana Geology (ed. K. S. W. Campbell), pp. 7-97. Canberra: Australian National University Press.

Banks, H. P. 1975 (b). The oldest vascular land plants: A note of caution. Rev. Palaeobot. Palynol. 20, 13-25.

Banks, H. P. 1975 (c). Reclassification of Psilophyta. Taxon 24, 401-413.

Banks, H. P. 1977. Plant macrofossils. In The Silurian-Devonian Boundary (ed. A. Martinsson). IUGS Series $A, 5,298-300$, Stuttgart. 
Edwards, D. 1970. Fertile Rhyniophytina from the Lower Devonian of Britain. Palaeontology 13, 451-61.

Edwards, D. 1979. A late Silurian flora from the Lower Old Red Sandstone of SW Dyfed. Palaeontology 22, 23-52.

Edwards, D. \& Davies, E. C. W. 1976. Oldest recorded in situ tracheids. Nature 263, 494-5.

Gensel, P. G. 1976. Renalia hueberi, a new plant from the Lower Devonian of Gaspé. Rev. Palaeobot. Palynol. 22, 19-37.

Gray, J. \& Boucot, A. J. 1977. Early vascular land plants: proof and conjecture. Lethaia 10, 145-74.

Heard, A. 1939. Further notes on Lower Devonian plants from South Wales. Q. Jl geol. Soc. Lond. 95, 223-9.

Ishchenko, T. A. 1975. The late Silurian flora of Podolia. 15 pls, 80 pp. In Russian. Kiev: 'Dymka' Scientific Publishing House.

Lang, W. H. 1937. On the plant remains from the Downtonian of England and Wales. Phil. Trans. R. Soc. 227 B, 245-91.

Nikiforova, O. I. 1977. Podolia. In The Silurian-Devonian Boundary (ed. A. Martinsson). IUGS Series A, 5, 52-64, Stuttgart.

Obrhel, J. 1962. Die Flora der Pridoli-Schichten (Budnany-Stufe) des Mittelböhmischen Silurs. Geologie II, 83-97.

Potter, J. F. \& Price, J. H. 1965. Comparative sections through rocks of Ludlovian-Downtonian age in the Llandovery and Llandeilo districts. Proc. geol. Ass. Lond. 76, 379-402.

Richardson, J. B. \& Lister, T. R. 1969. Upper Silurian and Lower Devonian spore assemblages from the Welsh Borderland and South Wales. Palaeontology 12, 201-52.

Schopf, J. M. 1975. Modes of fossil preservation. Rev. Palaeobot. Palynol. 20, 27-53.

Schopf, J. M., Mencher, E., Boucot, A. J. \& Andrews, H. N. 1966. Erect plants in the early Silurian of Maine. U.S. geol. Survey Prof. Pap. 550-D, D69-D75.

Botany Department

University College

P.0. Box 78

Cardiff CF1 $1 \mathrm{XL}$

\section{EXPLANATION OF PLATE}

Rhyniophytina from Capel Horeb Quarry, Wales.

Plate 1(a). Cooksonia hemisphaerica, Ludlow Series. NMW 7734G 1. $\times 15$.

Plate $1(b, c)$. Undetermined elongate sporangia, Ludlow Series. NMW 7734G 2 and 3. $\times 15$.

Plate $1(d)$. Cf. $C$. caledonica, Ludiow Series, NMW 77 34G 4. $\times 15$.

Plate $1(e)$. Branching specimen of Steganotheca striata, Ludlow Series, NMW $7734 \mathrm{G} 11 . \times 15$.

Plate $1(f)$. S. striata sporangium with rounded apex, Ludlow Series. NMW $7743 \mathrm{G} \mathrm{8} \times 15$.

Plate $1(\mathrm{~g})$. Branching specimen of Cooksonia sp., Ludlow Series, NMW $7610 \mathrm{G} 1 . \times 10$.

Plate 1(h). Cooksonia sp., Downton Series, NMW 77 34G 12. ×6.4.

Plate $1(i)$. Much branched ?fertile plant fragment, Downton Series. NMW 77 34G 13. $\dot{\times} 10$.

Plate $1(j)$. Elongate $S$. striata sporangium, Ludlow Series. NMW 77 34G 3. $\times 15$.

Plate $1(k)$. Squat $S$. striata sporangium showing surface striations, Ludlow Series. NMW 77 34G 6. $\times 15$.

Plate $1(l)$. Intact $S$. striata sporangium with extensive apical thickening, Ludlow Series. NMW 77 34G 5. $\times 10$.

Plate $1(m)$. S. striata sporangium from which most of the coalified residues have flaked off; outline of sporangium and striations remain, Ludlow Series. NMW 77 34G 7. $\times 15$.

Plate $1(n)$. S. striata sporangium, Ludlow Series. NMW 77 34G 10. $\times 15$.

Plate $1(o, p)$. S. striata intact sporangium with apical thickening, Ludlow Series. NMW $7734 \mathrm{G} 9$. Specimen photographed using incident light in Plate $1 o(\times 24)$ and under a Stereoscan electron microscope in Plate $1 p$ $(\times 25)$. 
Geol. Mag. Vol. 116, 1979, Edwards \& Rogerson, Plate 1, facing page 98.
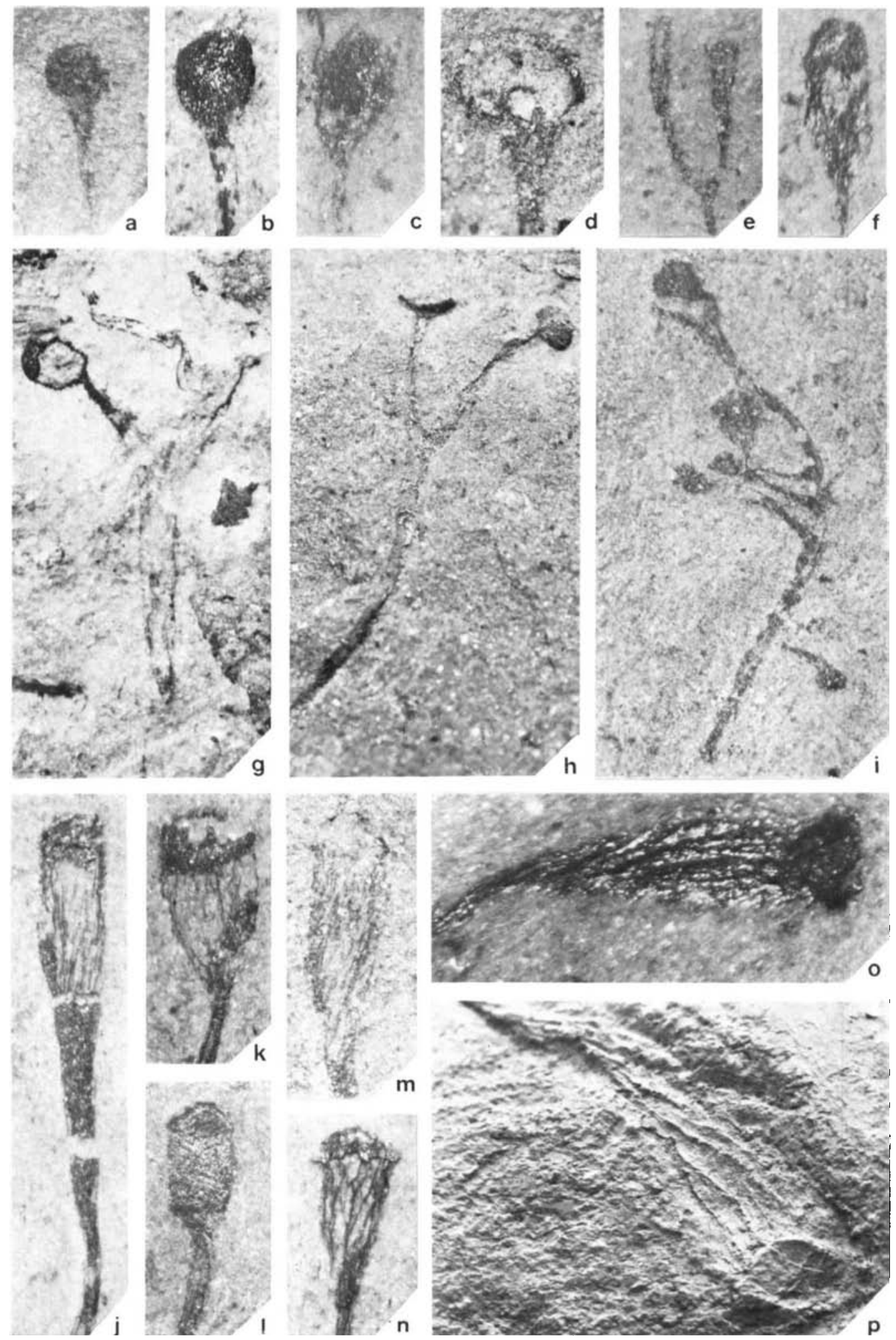

Plate 1. Rhyniophytina from the late Silurian, Wales. 